\title{
The Strategic Adaptation of Coal-Based Forest Village Community
}

\author{
${ }^{1}$ Hafizianor, ${ }^{2}$ Sugiyanto, ${ }^{2}$ Keppi Sukesi and ${ }^{3}$ Suprijanto \\ A Doctorate Program Student Faculty Of Agriculture in Brawijaya University ${ }^{I}$ \\ Faculty Of Agriculture, Lambung Mangkurat University, Indonesia ${ }^{2}$ \\ Faculty Of Agriculture, Brawijaya University, Indonesia ${ }^{3}$
}

\begin{abstract}
The change of biophysical and social environment as the effect of the change and the conversion of forest area into coal mining area has supported the villagers of forest village around the coal mining area to adapt so they can still exist as in a community and improve their welfare. This study aims to (1) analyze coal based forest village community's behavioral adaptation to the change of biophysical and social environment due to the change and conversion of the forest area into coal mining area (2) analyze all the strategic behaviors of the community of coal based forest village community in adapting to the change of biophysical and social environment because of the change and the conversion of the forest area into the coal mining area (3) formulate strategic adaptation models of the villagers of coal-based forest village towards the change of biophysical and social environment due to the change and conversion of forest area into coal mining area. This research was conducted in Tanah Bumbu Regency, South Kalimantan. The research method used to achieve these goals involved Miles and Huberman qualitative approach.

This research found that: (1) there were eleven adaptation behaviors of forest village community towards the change of biophysical environment and six adaptation actions of forest village community towards the change of social environment (2) there were seven strategic behaviors that outsource from eleven adaptation actions of forest village community towards the change of biophysical environment, which picture that there was a rationality in the way the community of forest village acted to do what they chose. Besides, there were six strategic behaviors that outsource from six adaptation behaviors from the community of forest village towards the change of social environment which is the response of the community towards the change of social environment that affects internally and externally (3) there were some strategic adaptation models of the forest village community oriented in four strategies in facing the change of biophysical and social environment.
\end{abstract}

Keywords: Adaptation behaviors, Strategic behaviors, and Strategic adaptations

\section{Introduction}

The main problem that faced by the community of forest village located in the area of coal mining is related to their accessibility and dependency in using the land and forest products that are limited due to the change and conversion of the forest area into coal mining area. The forest area used to be the livelihood, arable land, the functions of protection, and climate functions which could be used by the community of the forest village directly or indirectly. However, by the appearance of coal mining activities in the forest area, the significant change of biophysical environment happens and affects the change of social environment.

The change in biophysical and social environment as the effect of the change and the conversion of forest area into coal mining area has pushed the community of forest village around the coal mining to adapt so they can live on as an individual or as a community to preserve their existence and improve their welfare. This adaptation, in terms of sociology, is often known as ecology and socio cultural adaptations

Nevertheless, the adaptation can be done by the community of coal-based forest village affected by the change and the conversion of forest area into coal mining area which not only aims to take care of the balance, but also to change the existing condition to achieve a new condition that is actually expected. This adaptation is based on the strategic behaviors and strategic adaptations that are grounded on certain strategic behaviors existing in the community of forest village. Therefore, to comprehend how these adaptation behaviors, strategic behaviors and strategic adaptations of coal-based forest village community affect the change of biophysical and social environment because of the conversion of forest area into coal mining area, this research is necessary to be conducted in order that the strategic adaptation model of the community of coal-based forest village towards the change of biophysical and social environment due to the conversion of forest area into coal mining area can be formulated, which can be one of practical supporting capacities and academics for every party's businesses in comprehending strategic adaptation of the community of coal-based forest village.

Based on the background of the research problems as aforesaid, this research generally aims to analyze and formulate the strategic adaptation of coal-based forest village community towards the change of biophysical and social environment because of the change and the conversion the forest area into coal mining area. 
Specifically, this dissertation aims to (1) analyze coal based forest village community's behavioral adaptation towards the change of biophysical and social environment due to the change and conversion of the forest area into coal mining area (2) analyze all the strategic behaviors of the community of coal based forest village community in adapting with the change of biophysical and social environment because of the change and the conversion of the forest area into the coal mining area (3) formulate strategic adaptation models of the villagers of coal-based forest village towards the change of biophysical and social environment due to the change and conversion of forest area into coal mining area. The use of this research is to be the scientific contribution in sociology study in general; and sociology of forestry specifically, especially in relation to the strategic adaptation problems of the community of coal-based forest village in facing the change and conversion of forest area into coal mining area as an input for the competent parties (local government) as material appeal in formulating the development program which takes a side for the community, especially the community of forest village who live around coal mining area.

\section{Research Methods}

The research was conducted in the following three locations: Bukit Baru village Satui sub-district, Teluk Kepayang village Kusan Hulu sub-district, and Mantewe village Mantewe sub-district. These locations are located in Kabupaten Tanah Bumbu. This research was analyzed by using qualitative approach grounded on interaction model by Miles and Huberman which was completed with Bloom Taxonomy analysis in the main purpose and SWOT analysis in the third purposes. According to Moleong, qualitative data analysis by using Miles and Huberman model as excerpted in Moleong, (2010); Idrus, (2009); Sugiyono, (2011) is an interaction analysis model that consists of three activity channels happening simultaneously after the data collection processes so that they are capable of picturing a systematical, factual and accurate condition which really happens in the field in relation to the strategic adaptation of the community of coal-based forest village that includes these stages: (1) data reduction, (2) data display, (3) conclusion drawing or verification.

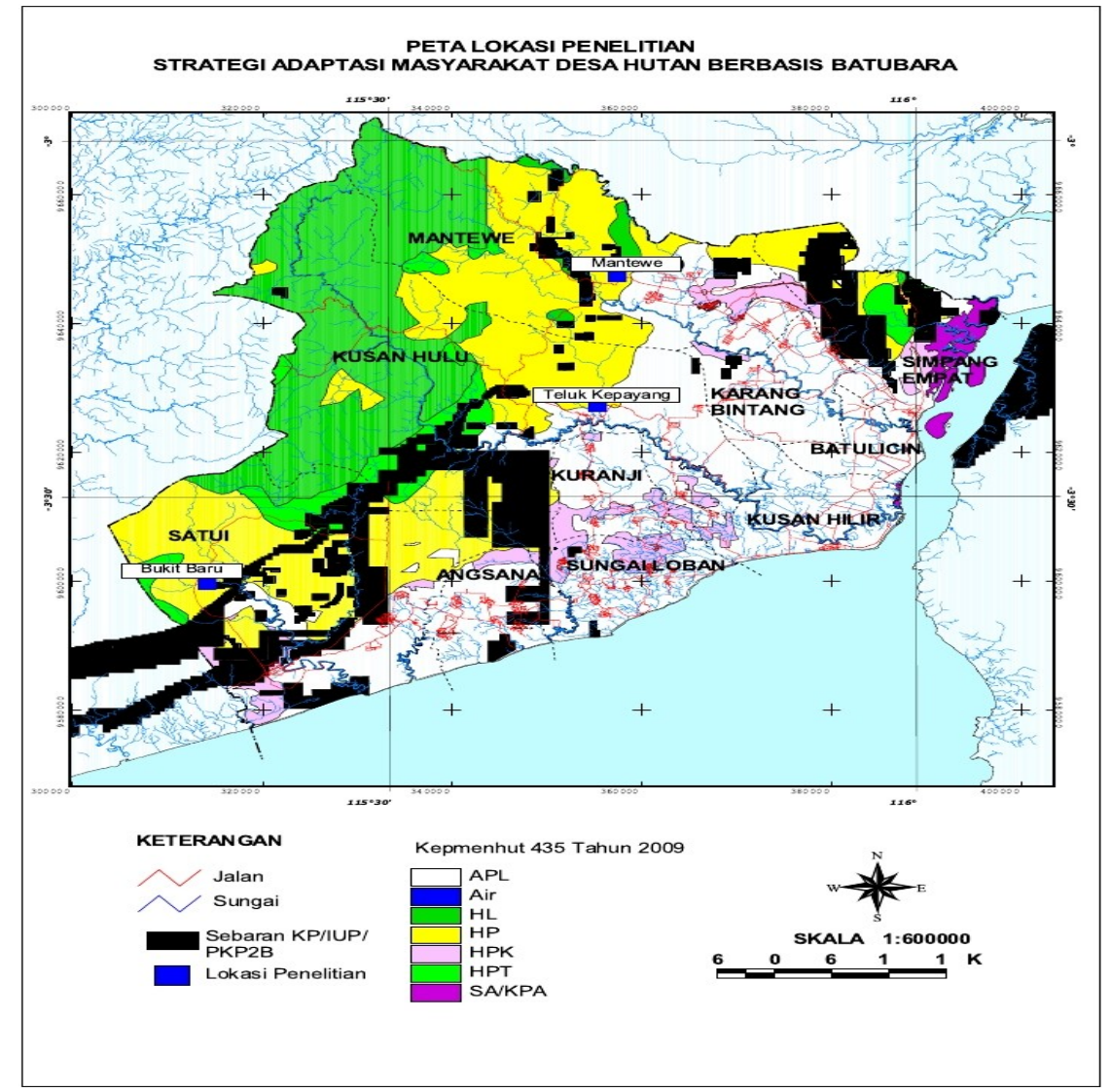

Fig. 1. Research Location Map 


\section{Empirical Result \\ The Adaptation behaviors of Coal-Based Forest Village Community towards the Change and the Conversion of Forest Area into Coal Mining Area}

In cognitive domain, the behavioral adaptation of the forest village community in adapting to the change of biophysical and social environment as the result of the change and the conversion of forest area into coal mining area includes knowledge, comprehension, application, analysis, synthesis and evaluation. From their knowledge point of view, those adaptation behaviors illustrate that there was a combination between the local knowledge owned by the community and the modern knowledge which was derived from the internalization processes after there was a socialization process from outside directly or indirectly. The local knowledge is the knowledge concept that comes from local and traditional experiences, while modern knowledge outsources from hypothesis testing by using the natural theories and rules. These behaviors outsource from local knowledge such as the shifting cultivation, shortening the shifting cultivation time, collecting the forest products, taking care of and using the intervention of the former farm fields, associative relationship with the migrants, and the development of social media. These behaviors do not appear from the intervention, socialization or education processes which outsource from the influence of external parties of the forest village community. Along with the research of Wreford and W.N. Adger, (2010) mentioning that from time to time the farmers are always capable of learning from their past experiences and the adapting processes. Adesina AA, Chianu J (2002) states that some farmers in Nigeria adopt the experimental technology by configuring different adopted technologies. It is essential to make continuous efforts to adapt with the technology variation in order to be more appropriate with the farmers' needs.

Modern technology brings settled cultivation, diversification of rubber and oil palm plantation, application of Agro-forestry in the yards, the process of digging and drilling wells, the improvement of village infrastructure, the use of technology in farming activities, diversification of livelihood with double earning pattern, the claim of the farming area with the system of ex-gratia compensation mechanism, and the bargaining in the company by using CSR program. These behaviors appear through the intervention, socialization, or education processes which outsource from the influence of external parties of the forest village community. It goes hand in hand with the research of Berman et. al (2012) mentioning that institutional roles (external parties) in transformational adaptation that is continual will support the better comprehension and affect the village community's ability to increase the adaptive capacity. The existence of that institution will also help informing the adaptation plan to the village community that they are able to achieve their dream of the future.

Community's behavioral adaptation that outsources from local knowledge, if seen from cognitive domain hierarchy, has covered all the phases from knowledge, comprehension, application, analysis, synthesis to evaluation. Cognitively, the forest village community has comprehended the adaptation actions that they do well because the adaptation outsources from the experiences from their ancestors. The appearance of the behaviors to do shifting cultivation, shortening shifting cultivation time, picking up the products of timber and non timber forest, managing and using intervention in the former farm fields, the associative relationship with the migrants and the development of social media cognitively which outsource from spoken and visual cultures and the culture are inherited from their parents and grandparents. From those processes of inheritance, the internalizations happen and become the knowledge of the forest village community which emerges later on in the next generation. It means that they apply the behavioral adaptation by leaning through the local knowledge because it is based on their capability to comprehend, apply, analyze, synthesize, and evaluate the knowledge that they own so far. As the research of Van Glasenapp, Thornton (2011) on the farmers in Alfine Swill who is in the condition of the marginal socio ecology condition, the adaptation of a household in the environmental change can become the toughest unit of that environment. This adaptation is done by arranging the man power and production based on the traditional ecology knowledge that is owned.

In this development due to the influence from the migrants, especially the ones that come from transmigration, job seekers, and the industrial labors, there is a modern knowledge contribution that appears and colors the behavioural adaptation of the forest village community in responding the change of biophysical and social environment of the forest such as the behaviour of settled cultivation, diversification of farming land for rubber and oil palm plantations, the implementation of agro-forestry system in the yard, the process of making dug and drilled wells the improvement of village infrastructure, the use of the technology in agriculture, the diversification of livelihood with double earning patterns, the claim of the land by using ex-gratia system and the bargaining system with the company by using CSR. Nonetheless, this modern technology, if seen from the cognitive domain hierarchy, is still in the phase of knowledge, comprehension and application. Thus, this kind of behaviour have not been prevalent in the forest village community because half of them still wait for the processes of analysis, synthesis and evaluation phases from the behaviours outsourcing from the modern knowledge. 
This condition affects the affective domain in terms of receiving or attending, responding, valuing, organizing, and characterizing by a value or value complex. In the behavioural adaptation outsourcing from the local knowledge, these stages of hierarchy from affective side will be shown completely. The behaviours to do shifting cultivation, shortening the shifting cultivation processes, collecting the forest products, taking care of and using the intervention of the former farm fields, associative relationship with the migrants, and the development of social media can be responded by acceptance, perception and award that are open for half of the community of forest village because those behaviors have been organized in the community of forest village and become the characteristics if the forest village community holds the values which are visible in their daily lives. Unlike the adaptation behaviors of the forest village community that outsource from modern knowledge, affective domain is still in the phases of accepting and perception. The forest village community has not openly shown values which may lead to making the modern knowledge concept become more organized which later on can also become the part of the forest village community's characteristics in terms of value that this community holds in their lives.

However, if seen from psychomotor domain which has phases of perception, set, guided response, mechanism, complex overt response, adaptation, and origination, all behavioral adaptation of the forest village community has been in the phase of guided response where all adaptation behaviors have been seen well by the forest village community to be learned as a complex skill by having the physical, mental and emotional readiness to act. Furthermore, According to the analysis of Bloom Taxonomy on three hierarchies comprising cognitive or thinking hierarchy (knowledge), affective or behaving and valuing hierarchy, psychomotor or acting hierarchy, all of the adaptation behaviors hold some strategic actions taken by the community members of forest village in response to biophysical and social changes.

The adaptation behaviors performed by the forest village community in facing the environmental condition that changes are in line with the former adaptation researches in the different contexts of research like in the researches of Suharjito (2002); Yuliati (2011); Arafah et. al (2008); Sunarti et al. (2009); Aryadi (2010); Lewoleba (1991); Hidayah (1993); Mahzuni (2001). Based on those results of researches, the behavioral adaptation is also done towards the change biophysical and social environment that happens. Those adaptation actions tend to be futuristic and gradually affected by the influence of internal and external factor, so that the adaptation actions which are done by the community of forest village support those four theories: Parsons functional structural theory, Max Weber rational act theory, George $\mathrm{H}$. Mead symbolic interaction theory and Bennet, Rambo and Martin open system theory, which become the basis of this research. Those theories complete one another. The various adaptation behaviors which are not settled in one or two behavioral adaptation are suitable with the human resource that they posses, as the adaptation of fishermen in the coastal area who also performed adaptation behaviors as written in Helmi, A.Satria's research (2012).

According to Parsons' functional structural theory, it is stated that there are four important functions when a decision takes place that can be summed up as a scheme, AGIL. One of the functions is adaptation. Adaptation takes place as a system, the purpose of which is to prevent emergency external situation so that the subject can acclimatize to the changes of the environment in order to survive and to get what it needs. In short, the actions and decisions that the forest village community takes are influenced by the external factors that determine the individual as well as the social structure. Based on the rational actions posited by Max Weber, it is known that the adaptation behaviors and decision of the forest village community are performed by individual freely and every action is governed by internal factors (mind, soul, identity) of a person, not because of the external environment, quoted from Jhonson (1986). Blumer, as quoted by Paloma (2003) states that from symbolic interaction theory aspect posited by George H. Mead, that an action and decision are based on the four bases of actions which are impulse, perception, manipulation, and performance. Actions are also based on the meaning of interaction, and they are perfected when the interaction in the social process takes place. Meanwhile, in Open System theory, Bennet, Rambo, and Martin assume that the social system and ecosystem are a complete system that correlate and interact simultaneously. According to Iskandar (2009 between ecosystem and social system, there is an exchange of input and output where both interact and the interaction is called adaptation and selection pattern. The research done by Pramova et. al (2012) states that the ecosystem serves as an important service that helps people adapt to the variety of climates and changes. Knowing the importance of the ecosystem, ecosystem-based approach in regard to adaptation is very much necessary.

\section{Strategic Adaptation of Coal-based Forest Village Community towards the Changes and Conversion of the Forest Area into Coal Mining Area}

Among eleven adaptation decisions that the people of forest village community does in response to the changes of the biophysics environment, there are four strategic adaptation decisions that the people of coalbased forest village does toward the changes and conversion of the forest area into coal mining area. Among them are: (1) Strategic actions of settled plantation system, (2) Strategic actions of farmland diversification for 
rubber and oil palm, (3) strategic actions of developing well by digging or drilling to substitute for river water, (4) strategic actions of infrastructure maintenance.

Related to the adaptation behaviors of the forest village community in response to the changes of the social environment from 6 adaptation behaviors, there are four strategic adaptation actions of the coal-based forest village community toward the shift in term of function of the forest area into coal mining areas. Among them are: (1) strategic actions of building association between the native forest community and the visitors, (2) strategic actions of developing the social resources of the forest village people, (3) strategic actions of diversifying field of works with double occupation system to the forest village people, (4) strategic actions of bargaining position through Corporate Social Responsibility (CSR). The strategic action is the implementation of a rational adaptive behavior, maximum and success oriented. Behavior change adaptation schemes to strategic actions can be seen in Figure 2.

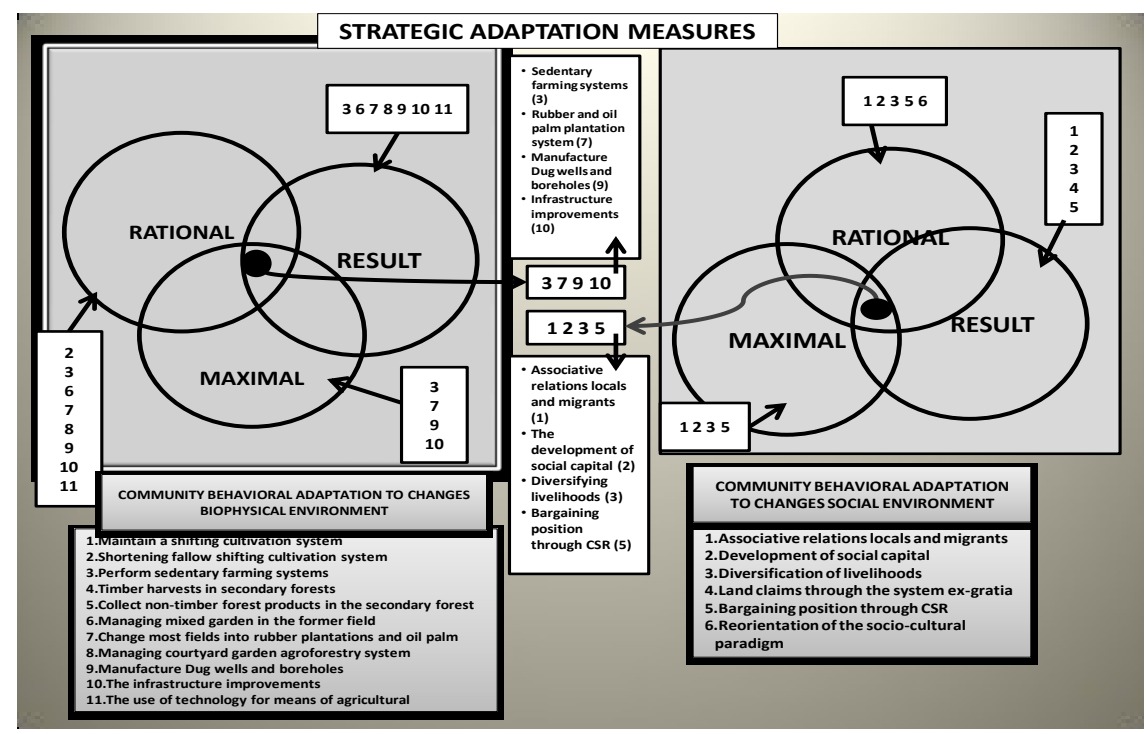

Fig.2. Strategic Action of Community Village Forest

The result of analysis from the research which discusses about the strategic adaptation actions of the forest village community due to the change of the forest area into coal mining area shows that: (a) Thera are four strategic decisions resulting from the eleven adaptation behaviors that the forest village community members perform in response to the changes in the biophysical environment depict the existence of rationality in the way the community in the forest village takes actions and determines choices available. The strategic actions cannot be done or applied on the familial level, but on the community level, it is more than possible. (b) There are four strategic actions performed in the adaptation of the forest village community which are based on six adaptation behaviors that the people of forest village community in response to the changes of the social environment that will affect the community both inward and outward. Affecting inward means the strategic actions are the effort of the forest village community to protect their position so that they can survive in overcoming the changes of the social environment. Affecting outward means the strategic actions serve as the improvement to the past experience which is proven to be too resilient to changes.

Henceforth, strategic adaptation done by forest village community, especially in overcoming the change in biophysical and social environment, proves Parsons' functional-structural theory, Max Weber's rational decision theory, and George H. Mead's symbolic interaction theory. Parson's functional-structural theory suggests that strategic adaptation (strategic actions in adapting to changes) is not separated from cultural system that grows in the familial or societal level that determines the interaction among family members and the head of the family. Consequently, the strategic adaptation is closely correlated with four systems of action posited by Parsons which govern among them the cultural, the social, the personal, and the organism system. Weber's rational action theory, however, is closely related to the forest village community strategic actions in selecting the adaptation suited to their condition so that the result of the selection will be strategic actions that have the characteristics of rational instrumental which is based on the clear objectives. In relation to George $\mathrm{H}$. Mead's interaction theory, the strategic action will reflect the cognitive capacity of the forest village community and also capture symbols of social phenomena among forest village people during the social process that happens during the changes in the biophysical and social environment, which is the result of the conversions of the forest areas into coal mining areas. 


\section{Strategic Adaptation of the Coal Forest Village Community towards the Changes and Conversion of Forest Area into Coal Mining Area}

To facilitate the model-building of the strategic adaptation that is done by village forest community in overcoming the changes and conversion of the forest area into coal mining areas, it is necessary to determine the key factors of success according to Internal Environment Analysis (IEA) and External Environment Analysis (EEA) that are based on SWOT analysis (Strength, Weakness, Opportunities, Threats). The strategy is designed through internal and external environment analysis by considering rationality, maximization, and achievement orientation. Internal Environment Analysis (IEA) consists of Strength and Weakness, while External Environment Analysis consists of Opportunities and Threats. According to Internal Environment Analysis (IEA) which consists of Strength and Weakness and External Environment Analysis consisting of Opportunities and Threats, the analysis of Strength, Weakness, Opportunities, and Threats scored an index of $2.890 .72,2.21$, and 0.90 , respectively. According to the index, it is known that the score of Internal Environment Analysis (IEA) was 2.17, while the External Environment Analysis (EEA) scored 1,31. Both of the scores were the results of deducting Weakness from Strength and Threats Opportunities. The score index of both Internal and External Environment shows a positive number, giving the impression that the Strength of the strategic adaptation is still higher than the Weakness and the Opportunities can still defeat the possible Threats. Therefore, it is necessary to use the correct strategic adaptation by forest village community in overcoming the changes and the conversion of forest area into coal mining area. This can be done by mapping the result of the score as outlined in Figure 3:

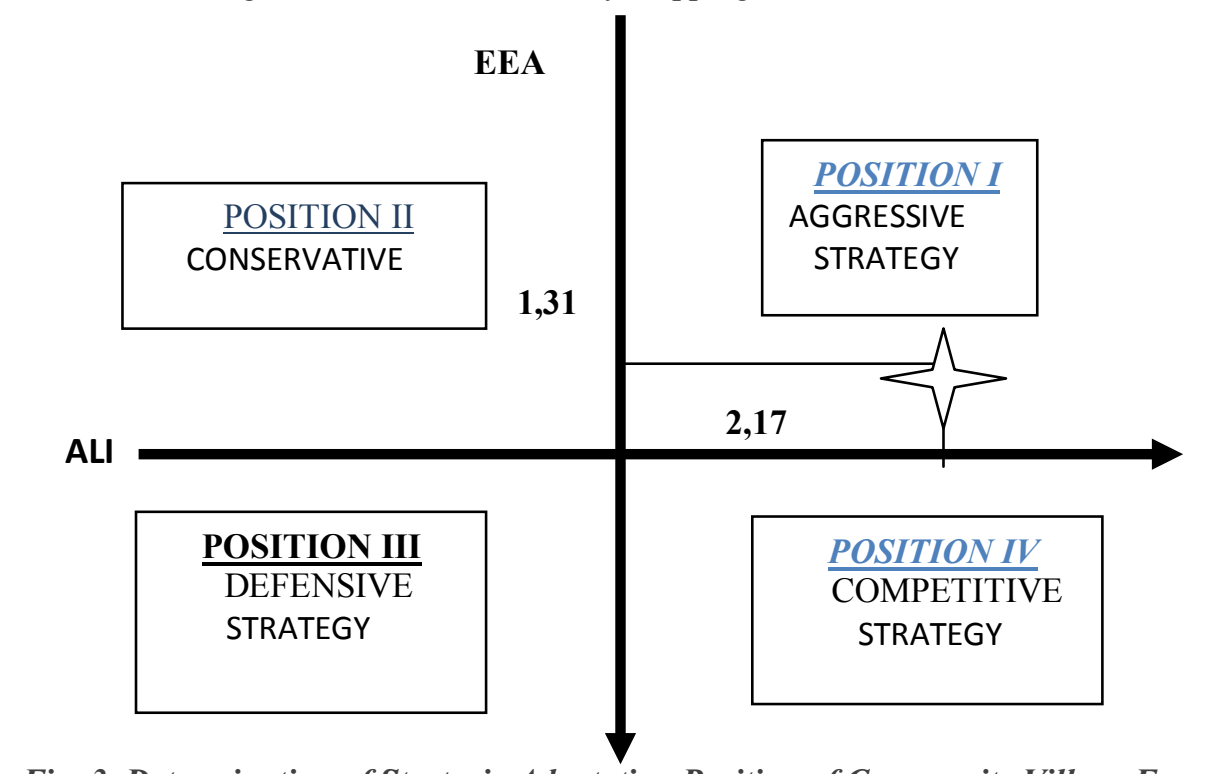

Fig 3. Determination of Strategic Adaptation Position of Community Village Forest

\section{INTERNAL ENVIRONMENT ANALYSIS (IEA) $\quad=2,89-0,72=2,17$ \\ EXTERNAL ENVIRONMENT ANALYSIS (EEA) $=2,21-0,90=1,31$}

According to the mapping projected from the results, it is known that the position of the forest village community is in correlation to the strategy I which is Aggressive Strategy. This shows that the strength of forest village community can capture the opportunities maximally while repairing the indentified weakness. Therefore, in deciding the strategy and the key factors of success on the strategy, it is necessary to point the aforementioned aggressive strategy. The next step is then to determine the forest village community strategy into four categories by considering the dominant position of the forest village community within the aggressive strategy that follows. Furthermore, the strategies which have been integrated and interacted will be represented by the strategy formulation using SWOT in an integrated table that will be followed by the last phase of SWOT analysis, determining key factors of success, by considering the intractability of the strategy with the strategic decisions and actions of the coal-based forest village community in adapting to the changes of biophysical and social environment due to the result of the change from the native forest area into industrial coal mining area.

The aforementioned strategic actions are actions and decisions taken based on the active actions barring on specific decisions and actions that are schemed with clear and measured objectives so that they have intractability with rationality, maximization, and achievement-orientation. To determine the key factors of success in a strategy, the highest result is done by adding the intractability index and the aforementioned three factors. These four elements contribute to the four key strategies of success, so that the index score is the highest among categories, which consist of SO, ST, WO, and WT categories. According to the order of the scores from 
the highest to the lowest, there are four strategies with highest scores that serve as examples and key factors of success for coal-based forest village community's strategic adaptation in overcoming the changes and conversion of forest area into coal mining areas. The four strategies are as follow: (1) Optimization of the people of forest village human resources in utilizing the available land resource through settled farmland system with intensification process for farming, rubber plantation, and oil palm plantation, (2) optimizing settled plantation with optimized maintenance of mixed field to substitute for the reduced land resource and available forest area, (3) stabilization of optimal CSR program development through the concept of community relation, community development and community empowerment to realize the autonomy of forest village community, (4) increasing the skills and versatility of the forest village community in technology mastery, settled farming system and plantation system, and rubber and oil palm plantations.

In accordance with the result of the SWOT analysis, forest village community strategic adaptation model oriented in the four strategies where, in overcoming the changes of biophysical and social environment, forest village community could adapt to the system and perform an adapted plantation and farming system as well as mixing forest produce. In order to incorporate strategic adaptation that is rational, maximal, and achievementoriented, there needs to be a system which utilizes settled farmland, oil palm and rubber plantation, maintenance of mixed plantation, as well as augmentation of human resources of forest village community so that they are capable of mastering the skills and capabilities of settled farming as well as oil palm and rubber plantation. In order for the human resources and the mastery of the skills and abilities of settled planting and farming to be accomplished, development of CSR program is made necessary and optimally constructed through the concept of community relation, community development, and community empowerment so that the forest village people will attain an attribute of autonomy as planned. Model adaptation strategies can be seen in the model adaptation scheme is shown in the following Figure 3. Based on the scheme of models emerging adaptation strategies in the agro-ecosystems that ensure diversification of agricultural activities that aim to be independent and well-being of forest villagers.

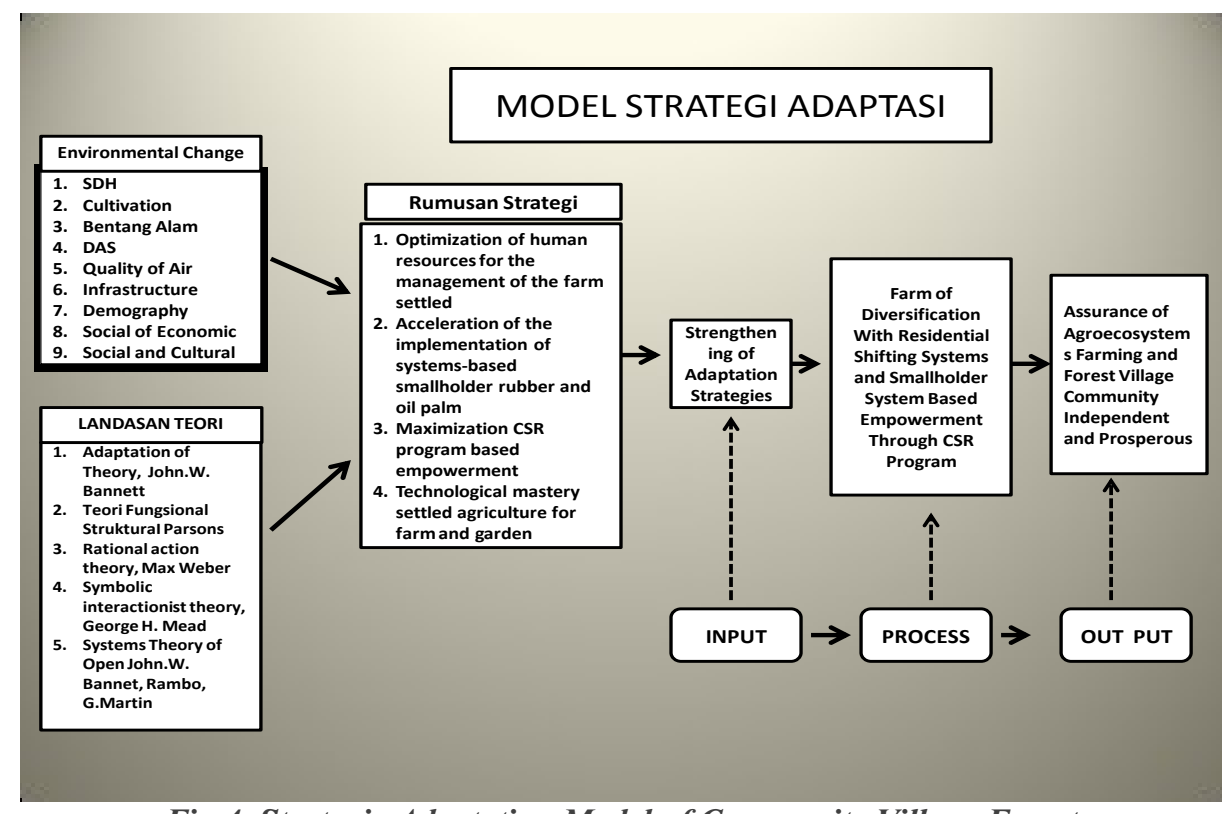

Fig 4. Strategic Adaptation Model of Community Village Forest

The strategic adaptation applied by forest village community supports the four theories (Parson's functional structural theory, Max Weber's rational actions theory, George H. Mead's symbolic interaction theory, and Bennet, Rambo, and Martin's Open System Theory) that served as the ground of the research. These four theories do not contradict one another; in fact, it complements each other. According to Parson's functional structural theory, it is said that transition process that happens goes toward stability within the social system, and the community evolution will direct toward the better adaptability system in order to achieve that stability, quoted from Parsons (1986). According to Max Weber's rational actions, the community actions in adapting to the changes are done by people with free will and choices and all of the actions are the result of internal factors within the people (soul, mind, self) and not because of the force of the environment, as quoted from Jhonson (1986). In addition, in his symbolic interaction theory, George H. Mead suggests that a symbol usually becomes the sign when a community is not being controlled by the environment where they live. According to Blumer quoted by Paloma (2003). According to Bennet (1976); Hidayat (2008) the community will become more active instead of passive in managing their own work. Meanwhile, Open System theory by Bennet, Rambo, and Martin 
assumes that selection and adaptation process are the process that takes place when social system and ecosystem correlate one another within an open system. Selection and adaptation serve to keep the balanced mutual relationship between ecosystem and social system so that the social system can survive through the flow of material, energy, and information. This breathes the same idea as the research conducted by Reed et. al. (2013), stating that the ability to adapt effectively and widely requires strategic adaptation scenarios whereas the adaptation serves as the synergy between poverty mitigation and ecosystem service conservation. Social and cultural factors also contribute the choices the community has in accordance with strategic adaptation. Research conducted by Arthur and D. Hilhorst (2012) states that the social climate change and the adaptation toward it must reciprocate the social process and the institution history that grows and goes in the way. According to Poerwanto (2000) who states that human and bio-geophysical environment relationship is not only about dependence, but also mutual and influential to one another and it is also capable of changing the bio-geophysical environment.

\section{Conclusions}

Due to the changes and conversion of the forest area into coal mining area, there were eleven adaptation behaviors that the forest village community performed in response to the changes in biophysical environment and six adaptation behaviors that the forest village community performed in response to the changes in social environment. All of the actions pointed toward future needs and were all influenced gradually by the internal and external factors.

Strategic actions and strategic decisions of the coal-based forest village community in adapting to the changes of biophysical and social environment due to the changes and conversion of the forest area into coal mining area were strategic actions taken and based on the direct actions, specific decisions that were schemed to achieve the objective with the strategic actions that revolved around rationality, maximization, and achievementoriented actions. There were four strategic decisions based on the eleven adaptation behaviors of the community in the forest village in response to the changes of the biophysical environment which depict the rationality on the decisions and actions of the forest village community in discovering and performing the choices that they have. In addition, there were four strategic decisions based on the six adaptation behaviors of the forest village community toward the changes of the social environment as a response to the changes of social environment that influenced them inside and outside.

There were some strategic adaptation models of the forest village community oriented in four strategies in facing the change of biophysical and social environment. Scheme of models adaptation strategies in the agroecosystems that ensure diversification of agricultural activities that aim to be independent and well-being of forest villagers.

\section{References}

[1]. Adesina AA, Chianu J. 2002. Determinants of Farmers' Adoption and Adaptation of Alley Farming Technology in Nigeria. Agroforestry Sys 55: 99-112.

[2]. Arafah, Nur, Dudung Darusman, Didik Suharjito, dan Leti Sundawati. 2008. Kaindea: Adaptation of Community Forest Cultivation in small islands.. JMHT. 15 (3): 130-136.

[3]. Arifin. 2008. Social Change in Rural Areas (A Study of Process and Impacts of Agricultural Land Conversion into Housing Development areas in Pakis Sub-district, Malang Regency). Dissertation of Brawijaya University. Malang. pp.407 (unpublished).

[4]. Aryadi, Mahrus. 2010.Cultural Adaptation of rural communities to Forest community Program. Dissertation of Brawijaya University. Malang. pp. 366 (unpublished).

[5]. Artur L, Hilhorst D. 2012. Everyday Realities of Climate Change Adaptation in Mozambique. Glo Clim Change 22: 529-536.

[6]. Bennet, John W. 1976. The Ecological Transition: Cultural Anthropology and Human adaption. Pergamon Press Inc. Oxford pp. 378.

[7]. Berman,R, Quinn C, Paavola J. 2012. The Role of Institutions in The Transformation of Coping Capacity to Sustainable Adaptive Capacity. Environ Develop 2: 86-100.

[8]. Hartati,Puji, 2008. Adaptation of Migrants in Society . Agrisystem Journal (4):2: (ISSN 1858-4330).

[9]. Hatu, Rauf A. 2010.Agricultural Land conversion into Sugarcane Plantations and its Impacts on Rural Communities (A case study on social changes among farmers in Tolangohula sub-district, Gorontalo Regency).Dissertation of Brawijaya University, Malang. pp 443 (unpublished).

[10]. Helmi,Avin Fadilla, 1994. Tougher Life in Cities: Adaptation Strategies in Densely-populated areas. Journal in Psychology (2) 2: 112.

[11]. Helmi, Alfian, A. Satria. 2012. Adaptation Strategies by Fishermen to Ecological Changes. Makara Journal, Social Humanities 16 (1): 68-78.

[12]. Hidayah, Zulyani. 1993. Talang Mamak and its environment: A case study on adaptation system of farming communities. Thesis of University of Indonesia. Jakarta. pp. 174 (unpublished).

[13]. Hidir, Achmad. 2004. Human Ecology and Social Changes. A Report of Library Research of Brawijaya University. Malang pp. 163 (unpublished).

[14]. Hidayat,Kliwon. 2008. Human Ecology. A textbook. Laboratory of Human Development and Communication of Social Economics, Faculty of Husbandry Brawijaya University . pp 134.

[15]. Idrus, Muhammad. 2009. Research Method in Social Science; Qualitative and Quantitative Approach. Erlangga. Jakarta. pp. 266.

[16]. Iskandar,Johan. 2009. Human Ecology and Sustainable Development. Master Program in Environmental Science of Padjajaran University. Bandung. pp 217. 
[17]. Johnson, Doyle Paul. 1986. Sosiological Theory, Classical Founders and Contemporary Perspectives. Robert M. Z. Lawang Robert (Translator). Teori Sosiologi Klasik dan Modern Jilid 1 . PT. Gramedia. Jakarta. pp 309

[18]. Johnson, Doyle Paul. 1986. Sosiological Theory, Classical Founders and Contemporary Perspectives. Robert M. Z. Lawang Robert (translator). Teori Sosiologi Klasik dan Modern Jilid 2. PT. Gramedia. Jakarta. pp 303

[19]. Lewoleba, Gregorius Goran. 1991. Adaptation Strategy by Farmers to Savannah Ecosystem: A case study in Amarasi sub-district, Kupang Regency,East Nusa Tenggara. Thesis of University of Indonesia. Jakarta. pp. 378 (unpublished).

[20]. Mahzuni, Dade. 2001. Fishermen Opposition as an Adaptation Strategy: A Study in Fishermen relationship - Bok in Banten Village, Serang Regency, Province of Banten. Thesis of University of Indonesia. Jakarta. pp. 185 (unpublished).

[21]. Moleong, Lexy J. 2010. Qualitative Research Methodology. PT. Remaja Rosdakarya. Bandung. pp. 410.

[22]. Parson, Talcot. 1986. Essays in Sociology translated by S. Aji. Aksara Persada Press. Jakarta. pp 439.

[23]. Poerwanto,Hari. 2000. Culture and Environment in Anthropological Perspective. Pustaka Pelajar. Yogyakarta. pp 304.

[24]. Paloma, Margaret M.. 2003. Contemporary Sociology. PT Rajawali Grafindo. Persada. Jakarta. pp 441.

[25]. Pramova,E, Locatelli B, Djoudi H, Somorin OA. 2012 . Forests and Trees for Social Adaptation to Climate Variability and Change. WIREs Clim Change 3: 581-596.

[26]. Reed,M.S., Podesta G, Fazey I, Geeson N, Hessel R, Hubacek K, Letson, D. Nainggolan D, Prell

[27]. C, Rickenbach M, Ritsema C, Schwilch G, Stringer LC, Thomas,AD. 2013. Combining Analytical Frameworks to Assess Livelihood Vulnerability to Climate Change and Analyse Adaptation Options. Ecol Econ 94: 66-77.

[28]. Sarman, Muchtar. 2004. Social Research Methodology. References of Social and Political Science Faculty of Unlam. Banjarmasin. pp163.

[29]. Simon, Hasanu. 2001. Cooperative Forest Management; Theory and Implementation in Teak Forests in Java. Bigraf Publishing. Yogyakarta. pp. 229

[30]. Suharjito, Didik. 2002. Talun-Kebun (Mixed-tree Garden): Social Cultural and Ecological Adaptation Strategies of Arid Land Farmers in Buniwangi Village, Sukabumi,East Java. Disertasi Universitas Indonesia. Jakarta. pp. 299 (unpublished).

[31]. Sunarti, Euis, Nia Nuryani, dan Neti Hernawati. 2009. Correlation between Adaptation Function, Objective Achievement, Integration, System Maintenance and Family Welfare. Family and Counselling Scientific Journals 2 (1): 1-10.

[32]. Sugiyanto. 2011. Lecturing Materials in Bloom Taxonomy (unpublished).Malang.

[33]. Sugiyono. 2011. Quantitative and Qualitative Research Methods and R\&D. Alfabeta. Bandung. pp. 334

[34]. Van Glasenapp,M, Thornton TF. 2011. Traditional Ecological Knowledge of Swiss Alpine Farmers and their Resilience to Socioecological Change. Hum Ecol 39: 769-781

[35]. Wreford, A, Adger WN. 2010. Adaptation in Agriculture: Historic Effects of Heat Waves and Droughts on UK Agriculture. Inter J Of Agric Sustain 8: 278-289.

[36]. Yuliati, Yayuk. 2011. Changes in Ecology and Adaptation Strategy of Tengger Society (A Study in Gender and Environment), Brawijaya University Press. Malang. pp. 299. 